\title{
Study of awareness of food labeling among consumers in North-West Russia
}

\author{
Mark Shamtsyan ${ }^{1}$, Boris Kolesnikov ${ }^{1}$, Mikhail Pushkarev ${ }^{1}$, Liviu Gaceu ${ }^{2,}$, Oana Bianca \\ Oprea $^{2}$, Iulia Iatco $^{3}$, Dumitru Mnerie ${ }^{4}$, Gabriela Mnerie ${ }^{4}$, Ovidiu Tita $^{5}$, Mihaela Tita $^{5}$, \\ Checilia Georgescu ${ }^{5}$, Monica Mironescu ${ }^{5}$, Stefan Stefanov ${ }^{6}$, and Stanka Damianova ${ }^{7}$ \\ ${ }^{1}$ St. Petersburg State Institute of Technology (Technical University), Moskovsky prospect, 26, \\ 190013, St. Petersburg, Russia \\ ${ }^{2}$ University of Transilvania of Brasov, B-dul Eroilor, 29, 500036, Brasov, Romania \\ ${ }^{3}$ Institute of Microbiology and Biotechnology, Academy of Sciences of Moldova, Chisinau, Moldova \\ ${ }^{4}$ Polytechnical University of Timishoara, Piata Victoriei, 2, 300006, Timisoara, jud. Timis, Romania \\ ${ }^{5}$ Lucian Blaga University of Sibiu, Bd-ul. Victoriei, 10, Sibiu, 550024, Romania \\ ${ }^{6}$ University of Food Technologies, blvd. Maritsa, 26, Plovdiv, Bulgaria \\ ${ }^{7}$ Angel Kanchev University of Rousse, 8 Studentska str., POB 7017, Ruse, Bulgaria
}

\begin{abstract}
A survey among the consumers of North-Western region of Russia (St. Petersburg and Leningradskaya oblast) was carried out, to determine awareness and understanding of food labeling, as well as usefulness of various elements of food labeling.
\end{abstract}

\section{Introduction}

The aim of food labeling is to provide consumers with information which may influence their purchasing decisions. Food labels are a source of information and most often the first means for directly connecting with a consumer however its potential is not always well exploited [1]. Labels may be an instrument for reinforcing generic claims and for establishing product differentiation, differentiation across food categories and within a specific category [2,3]. Nutrition labels are intended to help consumers choose more healthful foods [4-8].

It is reported that consumers use attributes such as serving size; ingredient list; the \% daily values; health and nutrient claims; price; and brands when making their food purchasing decisions $[9,10]$. Also, it appears that many consumers feel confident that they understand how to read labels and prefer using a food label than relying on their own knowledge [11].

The Russian Federation has very strict requirements for the labeling presented for foods. This approach is consistent with international practice and appears to be correct, because the food in any society are the most important commodities, and the manufacturer in such a relationship is the dominant subject: Consumers still have to buy food that normally exist. To protect consumers from abusive of manufacturers, numerous requirements to inform buyers have been developed.

\footnotetext{
${ }^{*}$ Corresponding author: gaceul@unitbv.ro
} 
Detailed, honest, and accurate labelling is essential to inform the consumer about the food product, enabling them to make a more informed and better choice.

While food shopping, consumers often look for distinguishing features of products to select among the many items available. Brands, labels, store signs, distinctive packaging, and other recognizable features help consumers distinguish one product from another [12].

The objective of this study was to determine if consumers adequately understand information on labeling currently presented on foodstuffs, as well as the efficiency of such labels to assist them make informed and correct purchasing choices.

We have carried out our survey to understand:

1. Whether consumers in the region of survey consult labels before purchasing food.

2. If information presented on labelling is sufficient for informed purchasing.

3. To determine if labels influence consumers' purchasing decision-making processes, and in which extend.

4. To ascertain whether or not consumers accrue benefits from the labels.

\section{Materials and methods}

A survey was carried out with 738 consumers, aged 16 years and older, across St. Petersburg and Leningradskaya oblast in North-Western region of Russia in January and February, 2019. Respondents were almost evenly spread according to gender, social class category and covered households which did and did not have children (Figure 1).

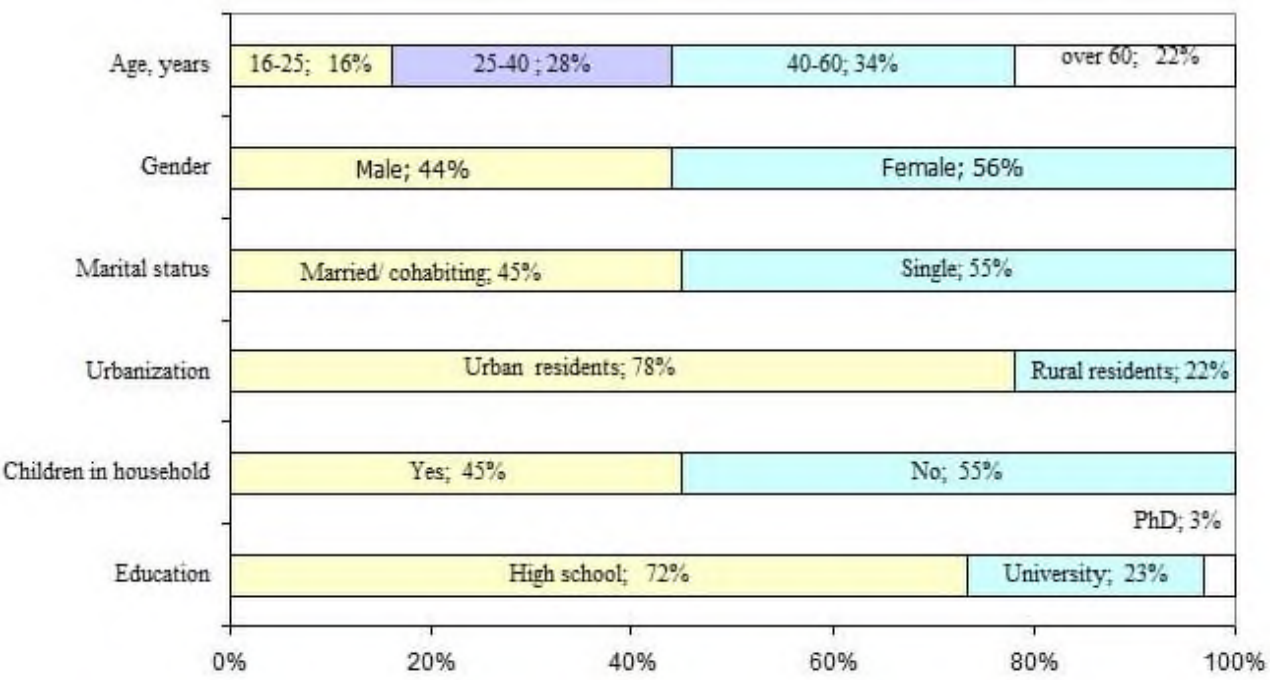

Fig. 1. Demographic profile of consumers participating in the survey ( $\mathrm{n}=738$ for all cases).

\section{Results and discussion}

\subsection{Purchasing habits}

The majority of consumers were involved in food shopping for their household, with two thirds buying more than half of the food shopping. Only 5\% $(50 / 1,021)$ of consumers said that they shopped for none or almost none of the household shopping (Figure 2). 


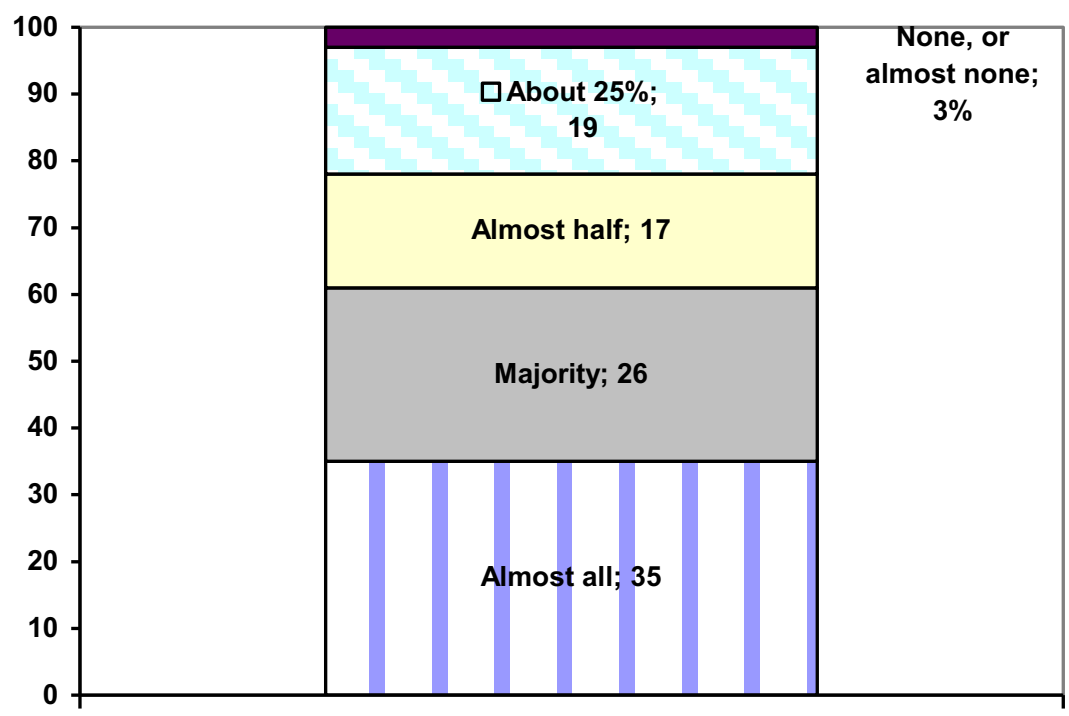

Fig. 2. Proportion of the household food shopping that the participant of the survey personally byes $(\mathrm{n}=738)$.

\subsection{Do consumers read food labels?}

Although more then a half of consumers said that they always or usually consult food labels when shopping for food, about quarter said they rarely or never consult them (Figure 3).

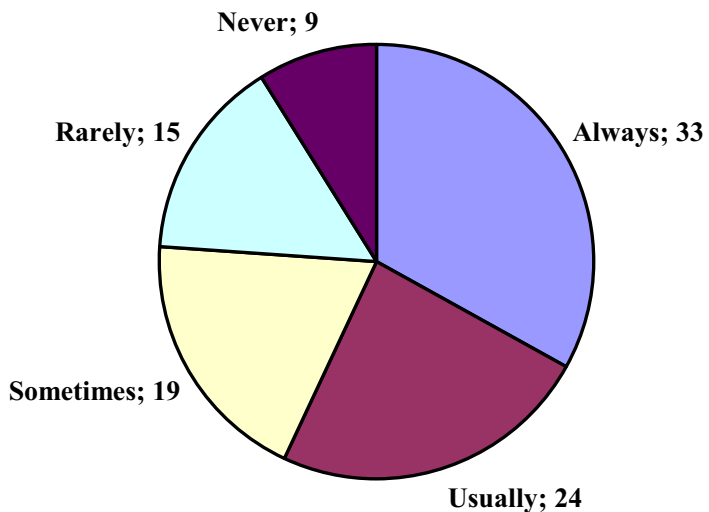

Fig. 3. Frequency with which consumers consult labels when shopping for food $(n=738)$.

When the consumers were asked about the reasons for not always reading the information on product labels, most of them answered, that this happens because they always bye the food of the same brands, based on their habits and previous positive experience, so they don't need to read the labels each time (43,9\% of all given answers). 
This was the only question of the survey, where consumers, if necessary, were able to select more than one answer (figure 4).

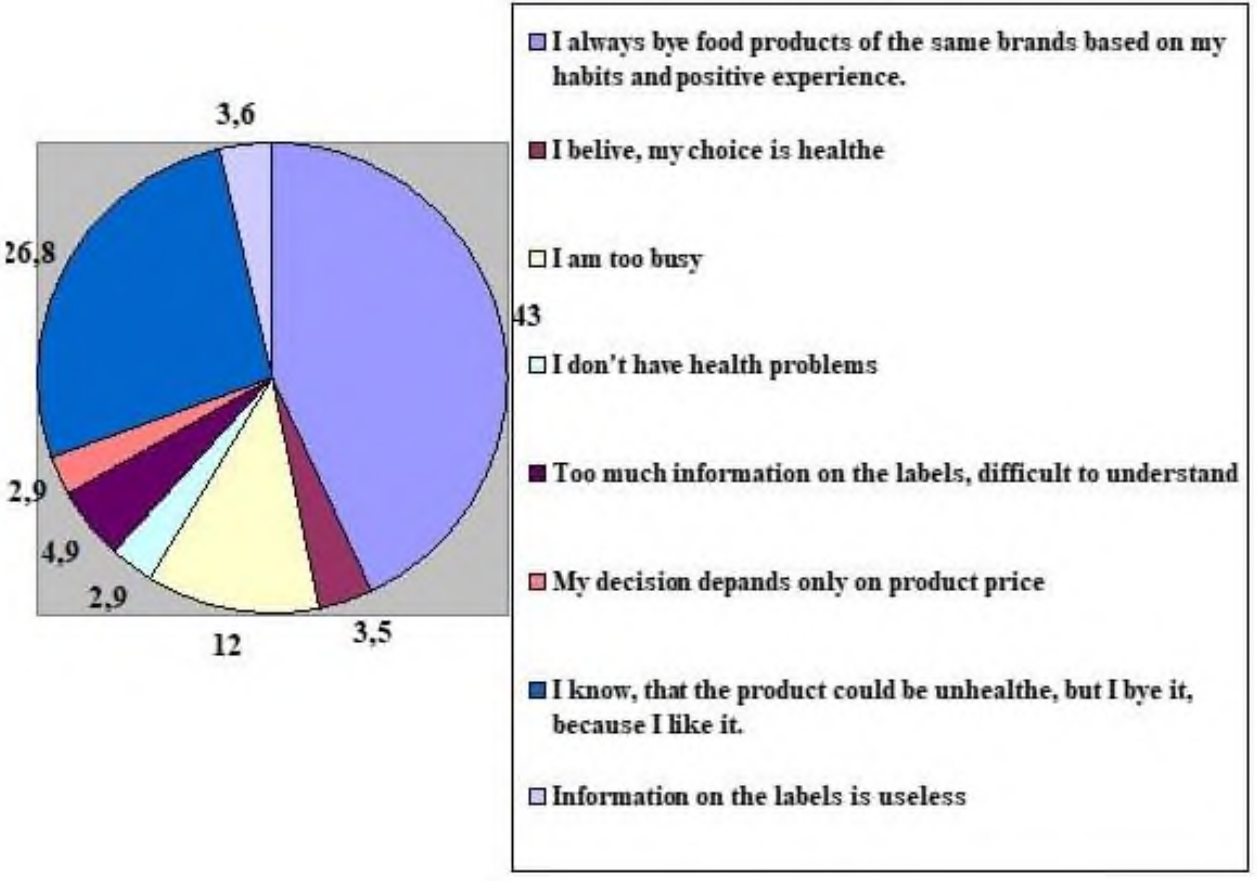

Fig. 4. Reasons for not always reading the information on product labels, $\%$ from the answers.

\subsection{What most influenced consumers decision to purchase a particular food?}

To understand what is influencing consumers decision to purchase one or another of similar types of food they were asked to select between, packaging design, product price, brand name and nutritional value. From the results of survey it could be concluded, that the product price and its nutritive value are the most important factors for the consumers making decision (figure 5).

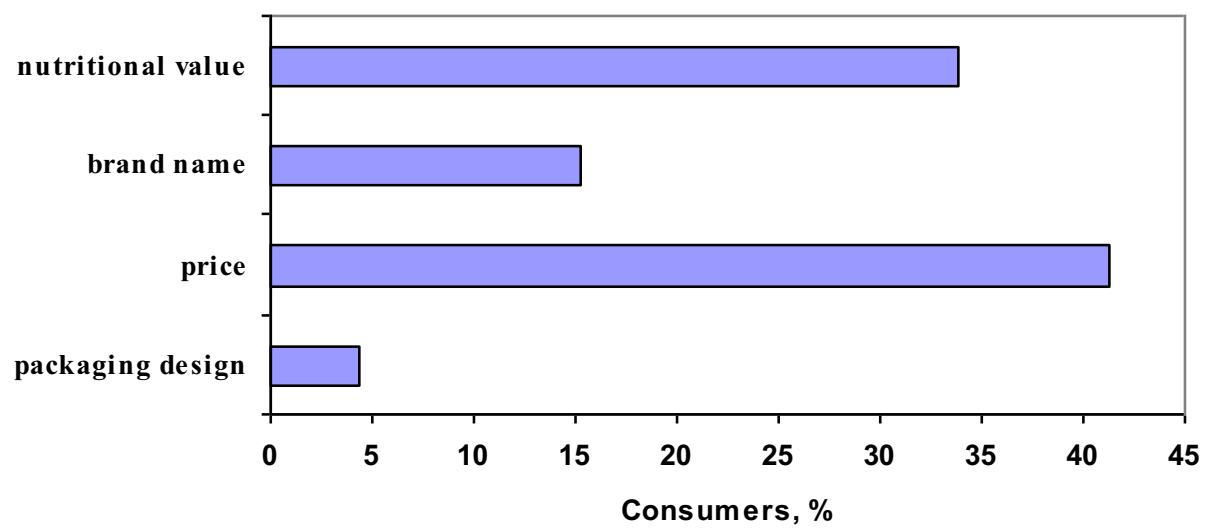

Fig. 5. What most influenced consumers decision to purchase a particular food $(n=738)$. 


\subsection{How informative are food labels?}

Interviewed customers were asked to estimate how accurate and complete information is provided in the labels of food products they consume. Estimation was done using the 10point scale, were 1- means totally insufficient information and .10- very complete information (Figure 6).

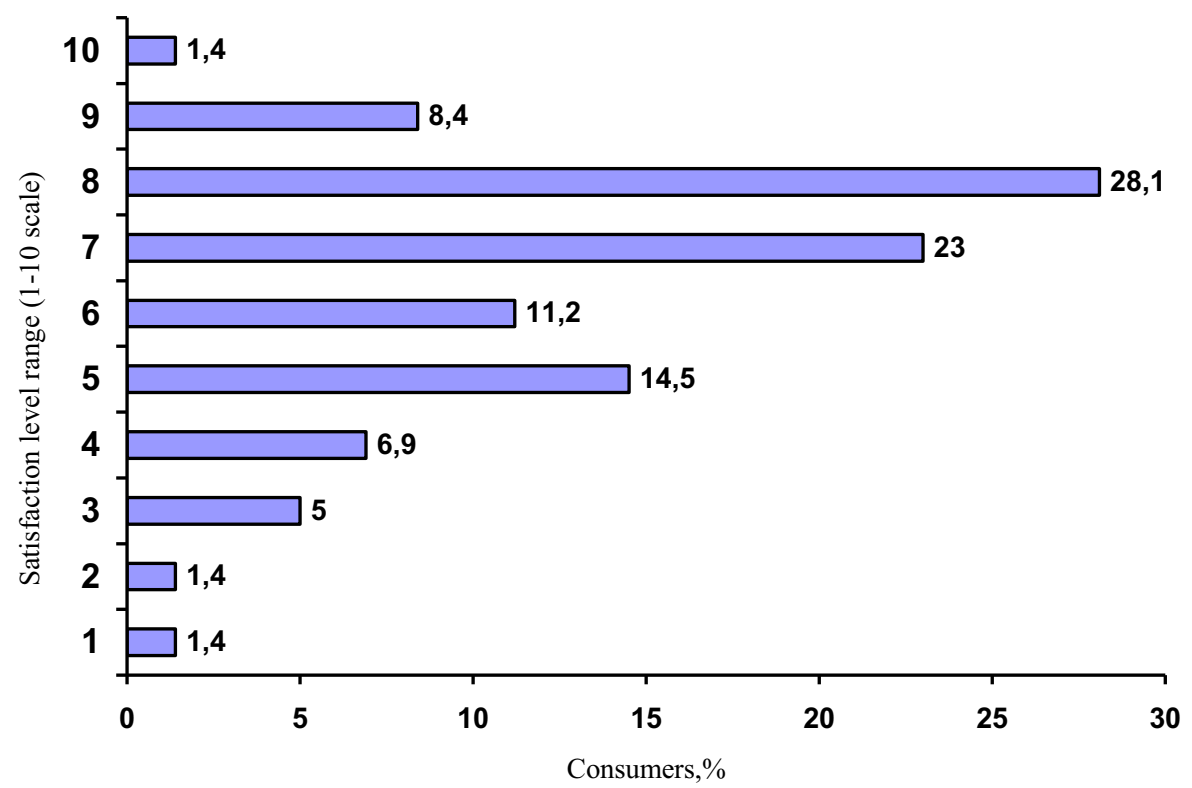

Fig. 6. How informative are food labels $(\mathrm{n}=738)$.

The ratio of the consumers, who consider food labelings not accurate and low informative (1-3 points on the 10 point scale) was less then $10 \%$. On the contrary, almost $60 \%$ of the consumers find food labeling accurate and informative (7-10 points based on 10 point scale).

\subsection{What is the degree of importance of various elements of the food labeling?}

To determine, which elements of food labeling consumers consider more important, and which - less, consumers were asked to distribute them into four categories according to the degree of importance. Results of the survey are presented in table 1.

Consumers valued as the most important the date of durability and the list of ingredients and the structure of the content. More then $90 \%$ of participants of the survey considered this elements of labeling information important or very important.

More then $2 / 3$ of consumers found important or very important information on substances or products causing allergies or intolerances, language, size and the color of the text from the label and special storage conditions and / or conditions of use.

In contrary, more then half of the surveyed consumers think of less important or not important information about the net quantity of the food and about the name and address of the manufacturer. 
Table 1. Importance of different elements of food labeling.

\begin{tabular}{|c|c|c|c|c|}
\hline \multirow{3}{*}{ Category } & \multicolumn{4}{|c|}{ Degree of importance } \\
\hline & $\begin{array}{l}\text { Very } \\
\text { Important }\end{array}$ & Important & Less importnat & Not important \\
\hline & \multicolumn{4}{|c|}{ Consumers, $\%$} \\
\hline $\begin{array}{l}\text { Country of the origin } \\
\text { of the manufacturer }\end{array}$ & 12,6 & 51,6 & 27,5 & 8,2 \\
\hline $\begin{array}{l}\text { The net quantity of the } \\
\text { food }\end{array}$ & 17,3 & 27,1 & 34,6 & 21,0 \\
\hline $\begin{array}{l}\text { Date of minimum } \\
\text { durability or ,valid } \\
\text { before" (date) }\end{array}$ & 86,4 & 10,0 & 1,2 & 2,4 \\
\hline $\begin{array}{l}\text { Name and address of } \\
\text { the manufacturer }\end{array}$ & 12,3 & 34,6 & 35,8 & 17,3 \\
\hline $\begin{array}{l}\text { Recommendations for } \\
\text { health }\end{array}$ & 31,8 & 28,3 & 22,8 & 17,6 \\
\hline $\begin{array}{l}\text { The list of ingredients } \\
\text { and the structure of } \\
\text { the content }\end{array}$ & 44,7 & 45,9 & 6,0 & 3,4 \\
\hline $\begin{array}{l}\text { Substances or } \\
\text { products causing } \\
\text { allergies or } \\
\text { intolerances } \\
\end{array}$ & 51,8 & 20,7 & 17,2 & 10,3 \\
\hline $\begin{array}{l}\text { Language, size and } \\
\text { the color of the text } \\
\text { from the label }\end{array}$ & 43,9 & 34,1 & 5,0 & 16,9 \\
\hline $\begin{array}{l}\text { Special storage } \\
\text { conditions and / or } \\
\text { conditions of use }\end{array}$ & 41,6 & 39,0 & 15,2 & 4,2 \\
\hline $\begin{array}{l}\text { Energy value, } \mathrm{kJ} \text { and } \\
\text { kkal }\end{array}$ & 19,5 & 36,6 & 25,6 & 18,3 \\
\hline $\begin{array}{l}\text { Quantity of the certain } \\
\text { ingredients or } \\
\text { categories of } \\
\text { ingredients }\end{array}$ & 13,8 & 51,9 & 26,6 & 7,7 \\
\hline $\begin{array}{l}\text { The content of: fat, } \\
\text { saturated, } \\
\text { monounsaturated, } \\
\text { polyunsaturated, } \\
\text { carbohydrates, sugar, } \\
\text { starch, salt, dietary } \\
\text { fiber, protein, } \\
\text { vitamins, minerals }\end{array}$ & 26,8 & 37,8 & 22,0 & 13,4 \\
\hline
\end{tabular}

\subsection{Consumers confidence in their understanding of the information presented on food labels.}

To determine in what degree consumers are confident, that they fully and in right way understand information presented in food labels, they were asked to appreciate, the level of knowledge that they have which enable them understanding of the content of the information on the food labels. Estimation was done using the 10-point scale, were 1means minimum level of knowledge and .10- maximum level of knowledge (Figure 7). 


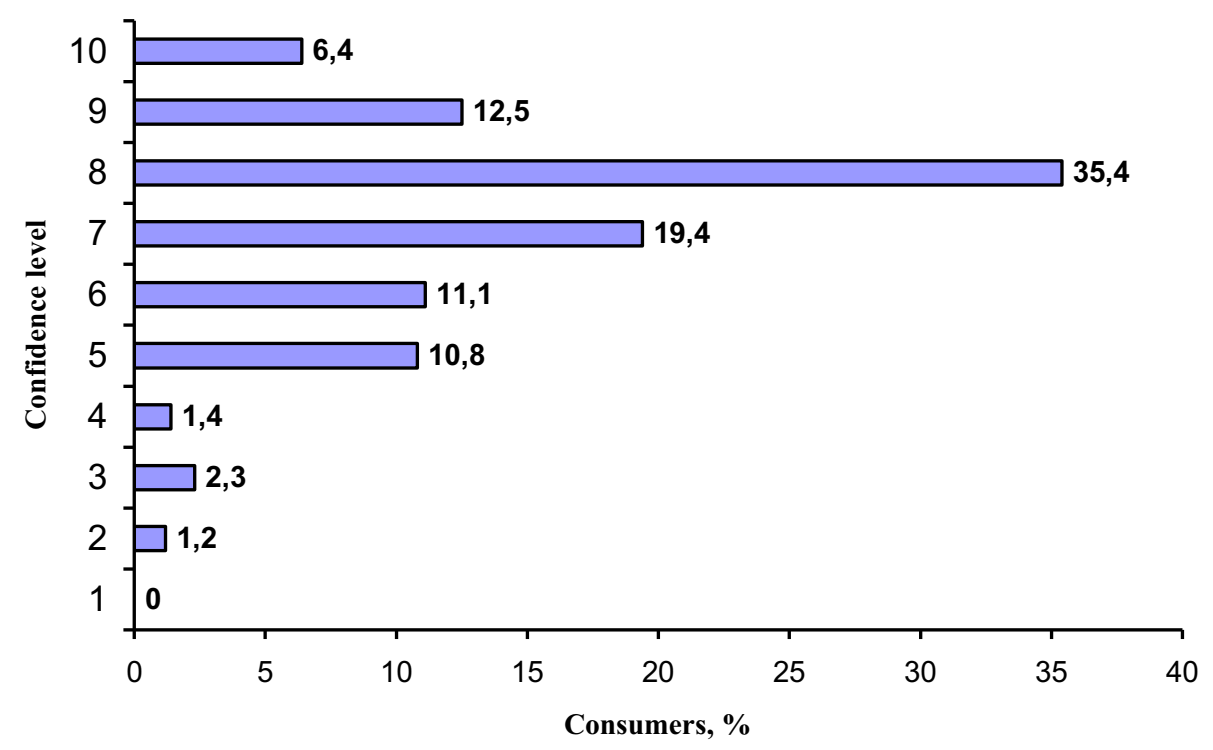

Fig. 7. Confidence level of the consumers in their own knowledge for full and correct understanding of the information presented in food labels.

Less then $5 \%$ of participants of the survey demonstrated low confidence in their knowledge and understanding (1-3 points on 10 point scale), while more then $70 \%$ of the consumers were highly confident in their understanding of labelings $97-8$ points based on 10 point scale).

In order to determine which of the elements of food labeling are better understood by consumers and understanding of which, on the contrary, causes difficulties consumers were asked to distribute them into four categories according to the degree of complexity of their understanding. Results are represented in the table 2.

Table 2. Consumers confidence in their understanding of the information presented on food labels.

\begin{tabular}{|c|c|c|c|c|}
\hline \multirow{3}{*}{ Category } & \multicolumn{4}{|c|}{ Degree of understanding } \\
\hline & $\begin{array}{l}\text { Very } \\
\text { easy }\end{array}$ & Easy & Difficult & $\begin{array}{c}\text { Not } \\
\text { understandable }\end{array}$ \\
\hline & \multicolumn{4}{|c|}{ Consumers, $\%$} \\
\hline List of ingredients & 29,8 & 51,8 & 14,6 & 3,8 \\
\hline Energy (calories, kJ) & 45,8 & 37,3 & 15,7 & 1,2 \\
\hline Proteins & 32,4 & 51,9 & 14,2 & 1,5 \\
\hline Fat content & 28,7 & 50,7 & 19,2 & 1,4 \\
\hline Cholesterol & 25,3 & 36,2 & 32,5 & 6,0 \\
\hline Carbohydrates & 40,5 & 45,3 & 10,7 & 3,5 \\
\hline Fibers & 20,7 & 33,7 & 30,1 & 15,7 \\
\hline Vitamins & 26,4 & 49,5 & 21,7 & 2,4 \\
\hline Sodium/salt & 35,0 & 39,0 & 22,1 & 3,9 \\
\hline Minerals & 28,9 & 38,5 & 25,2 & 7,5 \\
\hline The recommended daily dose & 43,5 & 38,8 & 11,4 & 6,4 \\
\hline $\begin{array}{l}\text { Terms of type - "no fat", "light", "low- } \\
\text { calories", "dietary product", "high in fibers" }\end{array}$ & 39,7 & 43,4 & 7,2 & 9,8 \\
\hline $\begin{array}{l}\text { The nutritional value (calories, proteins, ...), } \\
\text { per serving }\end{array}$ & 57,5 & 31,3 & 4,2 & 7,0 \\
\hline
\end{tabular}


It appears, that most of the consumers are highly confident in their knowledge levels, letting them to understand correctly all of the elements of food labeling, covered by this survey. The lowest is understanding of information on fiber and cholesterol contents, but even for these items $54,4 \%$ and $61,5 \%$ of consumers respectively answered, that they can understand information very easily or easily.

\section{Conclusions}

Survey results are demonstrating, that Consumers in the region of North-Western Russia consult labels before purchasing food and find information presented on labelling useful, important and in many cases sufficient for informed purchasing. Decision-making process of the consumers is usually influenced by product cost and information presented on the food labeling, as well as by their previous positive experience.

\section{References}

1. A. Annunziata, R. Vecchio, Factors affecting use and understanding of nutrition information on food labels: evidences from consumers, Agr. Econ. Rev. 13(2), 103-116 (2012)

2. J. Caswell, E. Mojduszka, Using Informational Labeling to Influence the Market for Quality in Food Products, Am. J. of Agric. Econ. 78(5), 1248-1253 (1996)

3. E. Golan, F. Kuchler, L. Mitchell, C. Greene, A. Jessup, Economics of food labelling, J. of Cons. Pol. 24, 117-184 (2001)

4. A. Banterle, L. Baldi, S. Stranieri, Nutrition Claims and Consumer Attitude: An Empirical Analysis in Italy, Proceeding of 103rd Seminar of the European Association of Agricultural Economists 'Adding value to the agro-food supply chain in the future Euromediterranean space' (Barcelona, Spain, 2007)

5. B.M. Hartmann, A.L. Vasquez-Caicedo, S. Bell, C. Krems, C. Brombach, The German nutrient database: basis for analysis of the nutritional status of the German population, J. of Food Comp. and An. 21, 115-118 (2008)

6. D. Mnerie, L. Gaceu, O. Gubenia, M. Shamtsyan, A. Birca, G.V. Mnerie, Comparative study on the evolution of the food labeling quality in some countries from the Black Sea region, J. of Hyg. Eng. and Design 14, 60-65 (2016)

7. M. Shamtsyan, Food legislation and its harmonization in Russia, J. Sci. Food Agric. 94, 1966-1969 (2014) doi:10.1002/jsfa.6197

8. C. Georgescu, A. Birca, M. Mironescu, M.A. Tita, M. Shamtsyan, I.D. Mironescu, O.Tita, Consumer perceptions of nutrition and health claims from food labels in Romania, J. of Hyg. Engin. and Design 16, 13-18 (2016)

9. P.E. McLean, An analysis of nutritional label use in the Southern United States, J. of Food Distr. Res., Food Distribution Research Society, vol. 32 (1) (2001)

10. E. Whitney, S.R. Rolfes, Understanding Nutrition (10th ed.) (WADS Worth, 55, 61, 2005)

11. S.L. Godwin, H.L. Speller, C. Thompson, Evaluating the nutrition label: its use in and impact on purchasing decisions by consumers, J. of Food Distr. Res. 37 (1) (2006)

12. A. Schupp, J. Gillespie, Consumer Attitudes Toward Labeling Fresh or Frozen Beef, J. of Food Distr. Res. V. XLII, (2), 34-44 (2001) 